\title{
STUDI STANDARISASI RADIOTERAPI COBALT-60 TERHADAP KUANTITAS SEL DARAH PADA PENDERITA KANKER SERVIKS (Cancer Cervics) DI RSUP SANGLAH DENPASAR
}

\author{
Retianingsih Oeta Ulan ${ }^{1}$, Gusti Ngurah Sutapa ${ }^{1}$, Wayan Balik Sudarsana ${ }^{2}$ \\ ${ }^{1}$ Jurusan Fisika, Fakultas Matematika dan Ilmu Pengetahuan Alam, \\ Universitas Udayana, Kampus Bukit Jimbaran, Badung, Bali Indonesia 80361. \\ ${ }^{2}$ Instalasi Radioterapi RSUP Sanglah Denpasar \\ Email : sutapafis97@unud.ac.id
}

\begin{abstract}
Abstrak
Telah dilakukan penelitian Studi Standarisasi Radioterapi Cobalt-60 Terhadap Kuantitas Sel Darah Pada Penderita Kanker Serviks (Cancer Cervics) di RSUP Sanglah Denpasar. Penelitian ini menggunakan data sekunder seperti tes darah lengkap dari masing-masing pasien penderita kanker serviks pada tahun 2015 yang melakukan radioterapi dengan metode fraksinasi. Jumlah data pasien yang digunakan pada penelitian ini adalah 5 buah. Kuantitas sel darah yang dianalisa meliputi RBC, HGB, WBC, dan Komponen WBC (LY, EO, EO, BA, NE, MO). Fraksinasi dosis adalah 800$5800 \mathrm{cGy}$. Hasil analisa data menunjukkan bahwa masing-masing komponen sel darah masih dalam rentang $2-50 \%$ sehingga metode radioterapi masih layak digunakan.
\end{abstract}

Kata Kunci : Fraksinasi, Kanker Serviks, Tes Darah Lengkap (TDL)

\begin{abstract}
After doing research with Title Study of Cobalt-60 radiotherapy Standards Against Quantity Blood Cells In Patients with Cervical Cancer (Cancer Cervics) at Sanglah Hospital in Denpasar. This study uses secondary data such as a complete blood from each patient with cervical cancer in 2015 that radiotherapy with fractionation method. The amount of patient data used in this study is 5 pieces. The quantity of blood cells that are analyzed include RBC, HGB, WBC and WBC Components (LY, EO, $E O, B A, N E, M O)$. Fractionation dose is 800-5800cGy. The results of data analysis showed that each blood cell components are still within the range of 2-50\%, so a method of radiotherapy is still fit for use.
\end{abstract}

Keywords: Fractionation, Cervical Cancer, Complete Blood Test (CBT)

\section{PENDAHULUAN}

Teleterapi Cobalt 60 memancarkan radiasi gama yang dapat dimanfaatkan untuk terapi pada penderita kanker serviks dan kanker peyudara. Kanker serviks adalah penyakit pembunuh wanita nomor satu di Indonesia. Tiap hari di Indonesia ada 40 wanita yang terdiagnosa menderita kanker serviks dan 20 wanita meninggal karena kanker serviks $^{[1]}$. Tiap hari di seluruh dunia sekitar 700 wanita harus meninggal karena kanker serviks. Akan lebih mengerikan bila kita melihat dari segi durasi kematian wanita yang meninggal karena kanker serviks. Setiap dua menit ada satu wanita yang meninggal dunia karena kanker serviks di dunia. Sedangkan di Indonesia, setiap 1 jam ada satu wanita yang meninggal karena kanker ganas ini. Keganasan kanker serviks di Indonesia ini didukung oleh sejumlah faktor. Pertama, karena memang kanker 
serviks bersifat sangat ganas. Kedua, banyak wanita yang belum mengerti mengenai gejala dan tanda-tanda kanker serviks ${ }^{[2]}$.

Radioterapi terhadap penderita kanker serviks akan menyebabkan perubahan terhadap produksi sel darah. Darah merupakan bagian penting dalam sistem sirkulasi tubuh. Darah terdiri atas dua bagian, yaitu bagian cair (plasma darah) dan sel darah. Sel darah meliputi eritrosit, leukosit, dan trombosit. Leukosit berfungsi sebagai sistem imunutas tubuh, yang terdiri dari monosit, eusinofil, basofil, limposit, neutrofil. Eritrosit bersama hemoglobin berfungsi dalam oksigenasi jaringan dan trombosit berperan dalam sistem pembekuan darah. Sel darah ini diproduksi di dalam sumsum tulang. Radiosensitivitas dari berbagai jenis sel darah ini bervariasi, sel yang paling sensitif adalah sel limposit dan sel yang paling resisten adalah sel eritrosit [3].

Dosis radiasi seluruh tubuh sekitar 0,5 Gy sudah dapat menyebabkan penurunan proses pembentukan sel-sel darah sehingga jumlah sel darah akan menurun. Penurunan jumlah sel darah ini akan sangat berdampak serius jika tidak segera ditangani karena darah mempunyai peranan penting terhadap fungsi tubuh manusia seperti imunitas, oksigenasi, hemostasis dan peran-peran lainnya ${ }^{[4]}$. Efek radiasi yang ditimbulkan oleh penyinaran teleterapi Cobalt 60 ini dapat diminimalisir dengan melakukan proteksi radiasi. Pemberian dosis radiasi secara fraksinasi bertujuan untuk mengurangi efek radiasi, karena dengan adanya dosis fraksinasi akan memberikan kesempatan pada sel sehat untuk meregenerasi dirinya. Simulasi yang dilakukan sebelum penyinaran untuk menentukan luas lapangan radiasi, arah penyinaran, jarak sentrasi dan sudut penyinaran harus cermat dan teliti sehingga terapi yang diberikan dapat membunuh sel kanker, tetapi efek pada jaringan sehat seperti sumsum tulang dapat diminimalisir [5].

\section{TINJAUAN PUSTAKA 2.1. Mekanisme Radioterapi}

Radioterapi bekerja dengan merusak sel DNA kanker. Kerusakan ini disebabkan oleh foton, elektron, proton, neutron, atau sinar pengion yang secara langsung ataupun tidak langsung mengionisasi atom yang membentuk rantai DNA. Radiasi pada jaringan dapat menimbulkan ionisasi air dan elektrolit dari cairan tubuh baik intra maupun ekstra seluler, sehingga timbul ion $\mathrm{H}+$ dan $\mathrm{OH}-$ yang sangat reaktif. Ion itu dapat bereaksi dengan molekul DNA dalam kromosom, mengakibatkan pecahnya rantai ganda DNA, perubahan cross-linkage dalam rantai DNA dan degenerasi atau kematian sel.

\subsection{Metode Fraksinasi Radioterapi}

Metode Fraksinasi dilakukan dengan pemberian dosis sebanyak 180 - 200 cGy perkali pemberian yang rata rata diberikan sebanyak 5 kali dalam seminggu dengan jumlah total 25 sampai 30 kali. Dengan metode ini sel kanker dapat dihentikan. Dasar metode fraksinasi pada radioterapi dikenal dengan istilah 4R yaitu: reparasi, redistribusi, repopulasi, dan reoksigenasi. Reparasi dan repopulasi merupakan proses yang diharapkan terjadi pada sel normal sehingga dapat mentoleransi besar dosis radioterapi yang diberikan. Reoksigenasi dan redistribusi merupakan proses yang diharapkan terjadi pada sel kanker untuk dapat meningkatkan kualitas radioterapi ${ }^{[6]}$.

\subsection{Darah}

Darah adalah cairan jaringan tubuh. Fungsi utamanya adalah mengangkut oksigen yang diperlukan oleh sel - sel di seluruh tubuh. Sel darah yang dibahas pada penelitian ini yaitu Red Blood Cell (RBC), Hemoglobin (HGB), White Blood Cell ( WBC), dan komponen WBC (Lymfosit (Ly), Eosinofil (EO), Basofil (BA), Neutrofil (NE), Monosit (MO). Darah juga menyuplai tubuh dengan nutrisi, mengangkut zat - zat sisa metabolisme, dan mengandung berbagai bahan penyusun sistem imun yang bertujuan mempertahankan tubuh dari berbagai 
penyakit. Komposisi darah dibagi menjadi dua bagian besar, yaitu: korpuskula: $45 \%$, plasma darah: $55 \%{ }^{[7]}$.

\section{METODE PENELITIAN}

Proses pengambilan data penelitian ini menggunakan data sekunder dibagi menjadi beberapa tahap:

a. Dipilih data pada pasien-pasien penderita kanker serviks dengan batas umur 20 hingga 50 tahun di tahun 2015. b. Data hasil laboratorium pasien penderita kanker serviks diolah dan dianalisis dengan excel dan spss versi 17.

\section{HASIL DAN PEMBAHASAN}

Data dari pengamatan pasien di dapatkan rata-rata seperti pada Tabel 1. Dari data pada Tabel 1 dapat direpresentasikan dalam bentuk grafik pada Gambar 1 dan Gambar 2.

Tabel 1. Rata-Rata Kuantitas RBC, HGB, WBC dan Komponen WBC pada penderita kanker serviks.

\begin{tabular}{|c|c|c|c|c|c|c|c|c|}
\hline \multirow{2}{*}{ Dosis } & \multicolumn{3}{|c|}{ Sel Darah $(\mu \mathrm{L})$} & \multicolumn{5}{c|}{ Komponen WBC( \% ) } \\
\cline { 2 - 9 } & RBC & HGB & WBC & LY & EO & BA & NE & MO \\
\hline 0(Sebelum & 4,21 & 11,94 & 13,05 & 15,06 & 2,58 & 0,12 & 58,28 & 5,4 \\
Pnyinaran) & $\pm 0,47$ & $\pm 1,53$ & $\pm 8,05$ & $\pm 10,29$ & $\pm 2,67$ & $\pm 0,10$ & $\pm 27,73$ & $\pm 2,72$ \\
\hline 800 & 4,31 & 12,38 & 8,23 & 15,06 & 2,58 & 0,12 & 76,16 & 3,90 \\
& $\pm 0,82$ & $\pm 2,42$ & $\pm 2,51$ & $\pm 6,62$ & $\pm 2,95$ & $\pm 0,44$ & $\pm 8,20$ & $\pm 0,45$ \\
\hline 1800 & 4,21 & 12,24 & 6,49 & 13,92 & 5,88 & 0,16 & 72,30 & 5,76 \\
& $\pm 0,65$ & $\pm 1,50$ & $\pm 1,48$ & $\pm 3,63$ & $\pm 4,56$ & $\pm 0,13$ & $\pm 5,77$ & $\pm 0,92$ \\
\hline 3000 & 4,16 & 10,35 & 6,8 & 11,74 & 4,14 & 0,16 & 66,58 & 5,18 \\
& $\pm 0,71$ & $\pm 6,05$ & $\pm 2,86$ & $\pm 5,50$ & $\pm 3,21$ & $\pm 0,87$ & $\pm 7,20$ & $\pm 0,99$ \\
\hline 3800 & 4,21 & 12,36 & 6,68 & 9,26 & 7,64 & 0,16 & 55 & 5,98 \\
& $\pm 0,79$ & $\pm 1,95$ & $\pm 1,27$ & $\pm 2,37$ & $\pm 4,53$ & $\pm 0,89$ & $\pm 4,23$ & $\pm 1,08$ \\
\hline 5000 & 3,5 & 10,84 & 4,39 & 12,32 & 3,6 & 0,16 & 60,87 & 7,26 \\
& $\pm 0,65$ & $\pm 1,34$ & $\pm 0,94$ & $\pm 3,58$ & $\pm 2,61$ & $\pm 0,15$ & $\pm 5,91$ & $\pm 1,35$ \\
\hline 5800 & 6,45 & 11,72 & 6,99 & 9,76 & 4,88 & 0,14 & 61,05 & 6,08 \\
& $\pm 4,28$ & $\pm 1,40$ & $\pm 3,62$ & $\pm 3,20$ & $\pm 2,47$ & $\pm 0,54$ & $\pm 6,27$ & $\pm 1,81$ \\
\hline
\end{tabular}

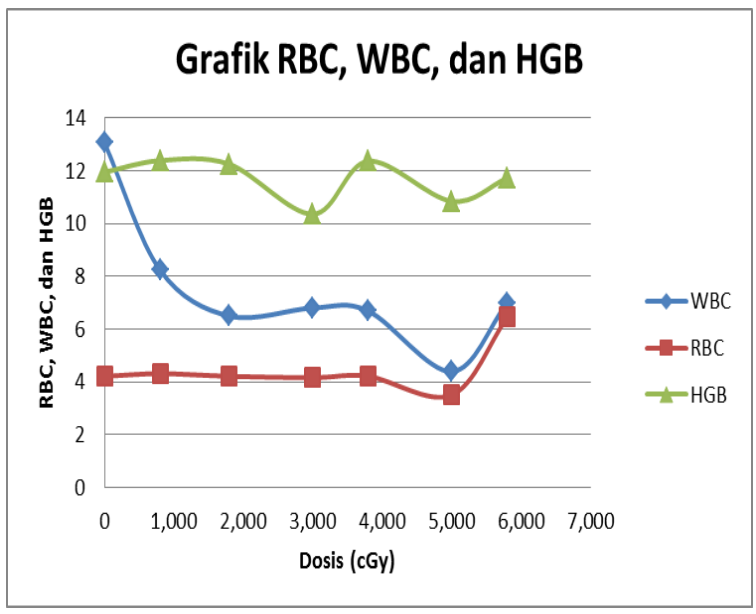

Gambar 1 Grafik kuantitas RBC, HGB, WBC

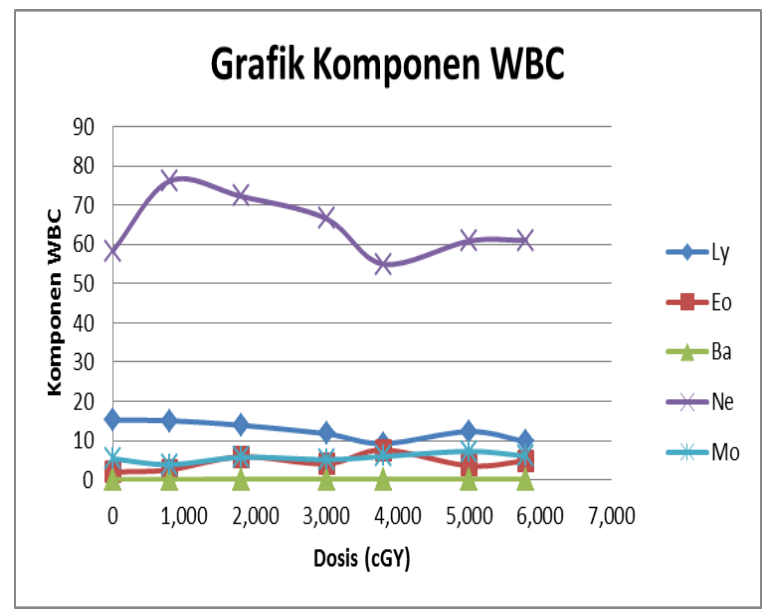

Gambar 2 Grafik Kuantitas Komponen WBC

Gambar 1 secara umum grafik RBC tidak menunjukkan penurunan atau peningkatan yang begitu tajam pada pemberian dosis 800-5000 cGy, untuk WBC terjadi penurunan mulai dari $800-5800 \mathrm{cGy}$ 
menunjukkan penurunan yang tidak begitu tajam atau sangat rendah, HGB terlihat cukup konstan dpemberian dosis 800-5800 cGy namun kalau dilihat dari Gambar 2 komponen sel darah khususnya pada $\mathrm{Ne}$ diawal menunjukkan peningkatan yang cukup besar dimulai dari 0-800 cGy, Akhirnya terjadi penurunan yang sangat rendah sampai dosis $5800 \mathrm{cGy}$.

Tabel 2 Persentase Perubahan Kuantitas Sel Darah terhadap kontrol.

\begin{tabular}{|r|r|r|r|r|r|r|r|r|}
\hline \multirow{2}{*}{ Dosis } & \multicolumn{8}{|c|}{ Persentase Perubahan kuantitas sel darah (\%) } \\
\cline { 2 - 9 } & \multicolumn{1}{|c|}{ RBC } & \multicolumn{1}{c|}{ HGB } & \multicolumn{1}{c|}{ WBC } & \multicolumn{1}{c|}{ LY } & \multicolumn{1}{c|}{ EO } & \multicolumn{1}{c|}{ BA } & \multicolumn{1}{c|}{ NE } & \multicolumn{1}{c|}{ MO } \\
\hline 800 & 100,02 & 100,04 & 99,63 & 99,99 & 99,44 & 100,00 & 100,31 & 99,72 \\
\hline 1800 & 100,00 & 100,03 & 99,50 & 99,93 & 100,00 & 100,33 & 100,24 & 100,07 \\
\hline 3000 & 99,99 & 99,57 & 99,52 & 99,86 & 99,70 & 100,33 & 100,31 & 99,96 \\
\hline 3800 & 100,00 & 100,04 & 99,51 & 99,84 & 100,60 & 100,33 & 100,29 & 100,11 \\
\hline 5000 & 99,83 & 99,91 & 99,34 & 99,81 & 99,61 & 100,33 & 100,27 & 100,34 \\
\hline 5800 & 100,53 & 99,98 & 99,54 & 99,83 & 99,83 & 100,17 & 100,36 & 100,13 \\
\hline
\end{tabular}

Dari Tabel 2 terjadi penurunan yang sangat rendah pada sel darah yaitu sekitar 0,01 - 0,14\%. Dari Tabel 2 persentase perubahan kuantitas sel darah masingmasing pasien dapat dipresentasikan dalam bentuk grafik seperti pada Gambar 3 .

Dalam penelitian ini menggunakan program spss versi 17 dengan uji Multivariate untuk mengetahui pengaruh dosis radisi terhadap sel darah dan uji Levene's Test untuk mengetahui pengaruh dosis radiasi terhadap masing-masing komponen sel darah.
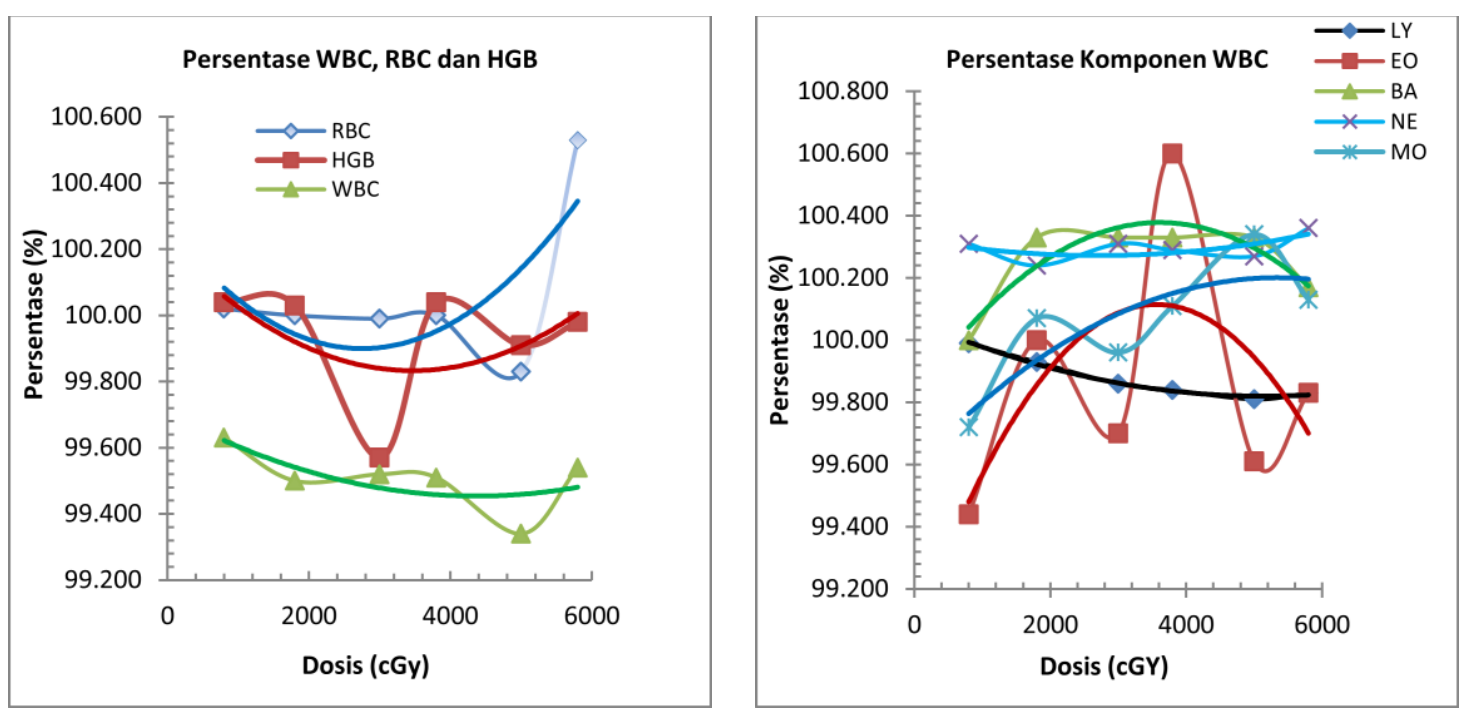

Gambar 3 Grafik Persentase perubahan kuantitas RBC,HGB, WBC, dan Komponen WBC

dan sesudah di radiasi. Komponen neutrofil dan lymfosit merupakan komponen WBC
Pada Uji Multivariate dapat dilihat ada pengaruh dosis radiasi terhadap sel darah secara umum, dapat ditunjukkan dari Hotelling's Trace nilai sig < 0,05. pada uji F hitung > dari $\mathrm{F}$ tabel dimana $\mathrm{F}$ hitung 2,435 sedangkan $\mathrm{F}$ tabel 2,363, begitupun dilihat dari probabilitas sig untuk Hotelling's Trace nilainya $0,00<0,05$ sehingga dapat dikatakan ada pengaruh yang signifikan dari dosis radiasi terhadap sel darah setelah di radiasi.

Pada hasil uji SPSS terjadi penurunan secara signifikan antara sel darah sebelum yang paling sensitif terhadap radiasi dan telah umum digunakan sebagai indikasi 
paparan radiasi [7]. Pada eosinofil, basofil, monosit mengalami peningkatan atau penurunan secara tidak signifikan antara sel darah sebelum dan sesudah di radiasi terhadap jumlah sel darah karena $F_{\text {hitung }} \geq$ $\mathrm{F}_{\text {tabel}}$, begitu juga terhadap perubahan sig eosinofil $0,05 \leq 0,59$, sig basofil $0,05 \leq 0,37$, sig monosit $0,05 \leq 0,120$.

\section{KESIMPULAN}

Dari penelitian ini analisa yang diperoleh menunjukkan bahwa hasil penelitian sel darah masih menunjukkan ada pada batasan $2-50 \%$, sehingga metode fraksinasi masih layak digunakan di Instalasi Radioterapi RSUP Sanglah Denpasar.

\section{DAFTAR PUSTAKA}

1. American Cancer Society (ACS). Global Cancer Facts and Figures 2nd Ediion. Atlanta: ACS ; 2011. WHO. 2013. Global Cancer Burden Rises TO 14.1 Million New Cases in 2012: Marked increase in breasts cancers must be addressed. Switzerland.
2. WHO. 2013. Global Cancer Burden Rises TO 14.1 Million New Cases in 2012: Marked increase in breasts cancers must be addressed. Switzerland.

3. Slonane dan Ethel. 2003. Anatomi dan Fisiologi. Jakarta : EGC.

4. Pearce dan Evelyn. C. 2005. Anatomi dan Fisiologi untuk Paramedis. PT Gramedia Pustaka Utama. Jakarta.

5. Nisa A. K., Juswono dan Martono. S. 2012. Efek Radioterapi Terhadap Produksi Sel Darah Pada Penderita Ca Mammae Dan Ca Cervix. Konsentrasi Fisika Medis. Universitas Brawijaya.

6. Susworo R. 2007. Radioterapi. Universitas Indonesia. Jakarta.

7. Campbell A. N., Jane B.R dan Mithel L. G. 2002. Biologi Jilid 3 . Edisi 5. Erlangga. 